\title{
THE CRISIS IN SCIENCE AND MATHEMATICS TEACHING
}

\author{
RALEIGH SchoRLING \\ The University of Michigan, Anin Arbor, Michigan
}

Who is going to teach science and mathematics in our high schools in the years just ahead? That should be the number one question in the minds of all thoughtful citizens. We will no doubt manage to get persons labeled emergency teachers into most science classrooms as caretakers of our youngsters. But what about the poor quality of teaching? That is the alarming threat to the welfare of our children, to the strength of this nation, and to the future of the world.

There is no need to recite in detail the facts picturing the drastic shortage of teachers in all fields of the high school. They have been recently hammered home in official government statistical reports, and in a dozen popular magazines, as for example, Good Housekeeping. The public at long last is alarmed. Politicians, ever quick to gear their speeches to popular thinking, do not make many speeches these days without a plea for a square deal for teachers. It is significant that Harold E. Stassen, when announcing his candidacy for the presidency, outlined a brief platform of four planks, of which one is to increase the salaries of white collar workers-especially teachers. Even the top flight radio comedians, as for example, Parkyakarkus, Fred Allen and Bob Hope seem to be alarmed about our vanishing teachers. Now that the salary of the school teacher is a grim joke we may be able to do something about it.

What's happening to our teachers? Many teachers of experience are leaving their classrooms. We are told that New York City alone lost 1000 during the last 12 months. In the war years competent teachers - especially science and mathematics- were useful in many branches of the Armed Forces. They learned that they were good at other jobs offering larger salaries, lighter work and greater freedom.

It is bad enough to have so many experienced teachers quitting but there is a far more disturbing fact: young persons are rejecting teaching in the lower schools as a career. This year nearly all colleges and universities are overflowing, but only a few per hundred are planning to teach. Last semester there were about 
200,000 students enrolled in 24 prominent colleges and universities* that educate teachers. This list includes state universities like the Univeristy of Minnesota and large teacher colleges as for example Greeley and Peabody. Note that these 24 schools had about $1 / 10$ of the 2 million students in our 1749 higher educational institutions. In these 24 institutions there were last semester only about 2200 students doing practice teaching-a course that all must take to qualify for the elementary and secondary schools. The number electing practice teaching this semester is no doubt much larger. Nevertheless the total number of students qualifying for the certificate this year in all institutions will be a small fraction of the 200,000 well qualified new teachers that we should have next fall.

What is the picture in these 24 schools as regards future teachers of science and mathematics for the high schools? In this vast student body of 200,000 there are only 450 who will this year qualify for the certificate in science and mathematics! My own school, the University of Michigan with more than 18,500 students, is perhaps typical. We have only 26 students--some not too strong - who will this year qualify in physics, chemistry, biology, general science or mathematics. The total number of student teachers in physics and chemistry for the year is 4; two of them with majors in chemistry, one with a minor in chemistry, and one with a minor in physics. Note that we do not have a single student with a major in physics who is planning to teach in high school.

The other large schools in our state present the same discouraging picture. Michigan has seven tax supported educational institutions that educate teachers. There are at present over 53,000 students in these seven schools-over $1 / 40$ of all students in higher education in the country-but there are only about 1300 who will some time during this year take practice teaching in an elementary grade or in some high school subject. There are 128 students among the 53,000 that will this year qualify as science teachers, including mathematics! Since there are more than 200,000 students in Michigan high schools study-

\footnotetext{
* Purdue University, Unjversity of Michigan, Eastern Illinois State Teachers College, Indiana State Teachers College, Michigan State College, New York State College for Teachers, New York University, Gcorge Peabody College for Teachers, University of Alabama, University of Iowa, University of Oregon, University of Southern California, University of Wisconsin, University of Nebraska, University of Virginia, Iowa State College, Grecley Teachers College, University of Kentucky, Indiana University, University of Washington, University of Connecticut, University of Kansas, Leland Stanford University, University of Minnesota.
} 
ing science and mathematics we need at least twice as many teachers of science as we now have in training and many, many more if we were to replace teachers with emergency certificates and the incompetent.

If we assume that our two samples as regards future teachers of science are typical of the whole population in higher education-2 million-one may venture the guess that we probably have only five or six thousand students in the whole country who will this year qualify as high school teachers of science and mathematics! We need at least twice this number to insure a good quality of science teaching.

The number of undergraduates majoring in science or mathematics and doing graduate work in these fields is probably a higher per cent of the total enrollment than it was ten years ago-certainly this is true at the University of Michigan. In 19 of these institutions with a total enrollment of about 150,000 there are at least 5000 undergraduates majoring in science and mathematics. In 18 schools with an enrollment of about 140,000 there are at least $\mathbf{2 0 0 0}$ graduate students specializing in science or mathematics. But they are not at present qualifying to teach science or mathematics in the high school. Ohio State University reports that it has $\mathbf{9 1 3}$ graduate students in the sciences including mathematics. It is not likely that as many as 50 will ever teach in high schools, or that 10 will ever teach secondary school mathematics. The young men in science are attracted so early by industry that they do not even bother to qualify for the teacher's certificate.

At the rate that industry, business and government are now picking up young scientists wer have no assurance that a high fraction of these 450 seniors doing practice teaching in science in these 24 training schools will be teaching science or mathematics in high school next fall.

The October 1946 number of Fortune prints a dramatic interview between Mr. Marshall, president of Raytheon, and a brilliant young physicist from MIT. The physicist asked what he would be expected to do at Raytheon. Whatever you like! He asked how much he would be paid. Whatever you like! The story, though a bit exaggerated, suggests the opportunities in industry for young men trained in science. The beginning salaries in some cases may be about the same. But the life expectance of total earning is several times as great for the young scientist in industry as in classroom teaching of science. 
We may note in passing that the outlook for enough good teachers in every high school field with the possible exception of physical education and music is dark. In the elementary grades it is hopeless in the years just ahead. Of the very small number of seniors in all our training schools who are taking the courses to qualify for the teachers' certificates, many will not even start teaching. The majority of women in this group will almost certainly quit before the end of three years. Keep in mind that young men nowadays have money for marriage early in life. The type of young woman who used to teach -in many cases quite effectively - for about three years, now is likely to get married within a year of her graduation from college. The stream of young people that used to flow into the teaching profession has just about dried up.

Don't count on the veteran to teach in high school. To be sure there are some veterans who taught before the war and who will stay in the teaching profession. But they are for the most part in graduate courses in education. Nearly all are mature men disciplined by heavy responsibilities who are definitely planning to be administrators, supervisors, college teachers, and technical workers. Moreover, they could not support their families on the low salaries that are now offered to them as classroom teachers. The University of Michigan alone has about sixty veterans who are planning to go all the way to the doctor's degree in professional education. They will, no doubt, be grand school men. But as teachers of your children, you might as well write them off your books. Of the miliion veterans now in school probably less than 18,000 will actually teach in high school unless they are driven to it by a future depression.

The problem of getting and holding men teachers in high school is becoming alarming. Men rejected teaching in the elementary school as a career long before the war. Today there are very few men teachers in the early grades of any large school system in the country. There is convincing evidence that men teachers are now disappearing from our high schools. Witness the fact that there are only seven men in a group of 96 students now doing practice teaching at the University of Michigan. Of these, one will enter the medical school next fall, one wants to be an agricultural agent under civil service, one is hoping to be a director of community recreation, one has an eye on Broadway, one will enter the graduate school, and one is planning to teach in a junior college. Only one lone man in this group has the fixed 
purpose of teaching in high school! Many thoughtful parents would like to have their children taught by a staff of which a third, or even a half are men teachers. Under existing conditions that will not be possible.

There is another cloud in the sky which should cause us concern. We have had a big increase in the birth rate during the war years. In the four year span, 1937 to 1940 inclusive, we had only about 9.1 million births, whereas in the 4-year period, 1941-44 inclusive, we had a little over 11 million. We had almost 2 million extra babies! Nor is the birth rate dropping as some believe, for it turns out that 1946 set an all time high. We have only a very few years to get ready for a wave of tots that will roll in on us in the form of a much larger enrollment in the early grades. Then we will need many additional teachers-certainly 50,000 , which is far more than the number of young people now in training who will actually go into the elementary grades. In fact we have less than 48,000 women in our 201 teachers colleges and normal schools who were enrolled in college before last fall. The problem will reach the science and mathematics departments in the high school about nine years hence.

By that time we are told we will have a critical shortage of young scientists. Persons who know best are estimating that we now have a deficit of 5700 Ph.D's in science and this is expected to become 15,000 by 1950 . Dr. Karl T. Compton estimates that we will need about 90,000 new engineers by 1950 . Colleges and universitics with their huge enrollments and the junior colleges now undergoing phenomenal expansion will beg industry and government in vain not to rob them of research workers and science teachers. We in the high school field may stand on the side line, watch the ruthless fight over good material and take shoddy leavings for teachers of high school science.

This, then, is the dark, hopeless picture throughout the country--it is true for your state and for mine. Where will we find enough good teachers? Unless we take certain definite steps, we probably will not find them.

The question is, what can we do? The answer, of course, is make teaching attractive to our youth. How can we make teaching a desirable profession for the students in our high schools and colleges? By taking out of the picture those things that now cause youth to turn away from teaching.

Let's look at some of their reasons. Consider first the matter of salary-not because it is the most important factor but because 
it is the one that can get public action quickly enough to help us in the immediate future. So much has recently been printed on the gap between the salaries of teachers and those in other lines of work that little need be said here on that point.

The favorite stunt in magazines and on the radio is to contrast the salary of a school teacher with that of the dog catcher, the rat exterminator, the garbage collector, the bartender, the elevator operator, the cotton picker, the janitor and maintenance man. Most well-informed persons are now probably aware that industrial workers in a typical town, if they do not lose wages through strikes average from $\$ 800$ to $\$ 1000$ per year more than the classroom teachers. They know that when a teacher's salary is contrasted with plumbers, painters, carpenters and technical workers in industry who need to devote three or four years to training for their job, that the gap is much wider-perhaps as much as $\$ 2,000$ per year in favor of the technical worker. However, they might be amazed if they made a study of the situation in their own community and discovered that about a fourth of their teachers get less than the commonest of common laborers.

How does the teacher with a family manage to live? The answer is by taking part-time jobs on top of a double load. For example Time December 23, 1946 reports that $\frac{3}{4}$ of the men and $\frac{1}{4}$ of the women in a group of 3500 teachers polled in New York City were doing side-line work to get along. Amazingly enough one teacher of the social siudies gets a salary of $\$ 51.25$ a week and $\$ 60$ a week for tending bar in part-time hours. He is quoted as saying that bartenders now discuss teacher salaries as "something terrible." Even principals of large high schools are driven to neglect their great responsibilities by taking an outside work to support their families.

The teaching profession includes an astonishing number per hundred who labor with high competence and missionary zeal regardless of compensation. For that we are grateful and proud, but a million persons do not year after year give themselves to any calling without appropriate salary. What really happens as has been suggested is that many of our best prospects for teaching are attracted by better paid jobs in industry, in commerce, and in the other professions.

Shameful as the salary situation is, there are about a dozen additional reasons why young people are choosing other fields of work. Most of these relate to the working conditions of teachers. It will be a fatal mistake if we assume that we can get and keep 
enough good teachers merely by doubling the salary of every teacher. When editors, columnists, cartoonists and comedians champion the cause of our teachers, salary and social status naturally are important. Basic as these matters are, we nevertheless will not come to grips with the problem of attracting enough young people of the right kind without adequate consideration of one other factor. In an earlier day affluent persons had slaves, governesses, and servants to aid them with such menial tasks as drawing water, hewing wood, and caring for children. Today most homemakers are better off in that they can turn on the faucet, set the thermostat and send the children to school. Any mother who takes care of three or four restless youngsters all day is weary by night and any father who has been so reckless as to try it is a wreck by noon. Yet a teacher who does far more than take care of children is expected to work with a roomful of children bour after hour.

There are about 12 things that need to be corrected. These were listed in a document entitled "An Evolving Bill of Rights," first published in 1945. Since this statement has been republished in more than 40 journals and used as a basis in articles and editorials in several hundred newspapers and magazines we need do no more here than to list the rights as follows:

1. The right to teach classes that are not too large, in general from ten to twenty pupils.

2. The right to have time in the school day for planning.

3 . The right of a 45 -hour week.

4. The right to adequate compensation for the full year of fifty-two weeks.

5. The right to an adequate amount of helpful and constructive supervision.

6. The right to have good materials and enough of them.

7. The right to work in a room that, with the help of the students, can be made pleasant and appropriate to the tasks to be learned.

8. The right to the same personal liberties which other respectable citizens assume for themselves as a matter of course.

9. The right to an internship.

10. The right to a realistic program of in-service education.

11. The right to participate in changing the curriculum and methods, and in formulating school policies.

12. The right to keep from being lost in the profession.

Obviously, any school board that sets up decent working conditions will have to spend more money for schools. The writer has seen many schools, but never a good one that did not cost a 
lot of money. There is no greater fiction abroad than the notion that the American people have been generous in the financial support of their schools. Any nation that spends more per year for chewing gum than for instructional materials and whose annual expenditure for education is only $\frac{1}{2}$ as much as for liquor, only $3 / 10$ as much as for cosmetics, only $\frac{1}{6}$ as much as for its Army and Navy in this, a year of peace, and only $\frac{1}{5}$ as much a for the care of criminals and delinquents is obviously not too much concerned about the education of its youth. Many parents interpret the phrase "free schools" to mean free as the air at the gas station. Some parents pay more to sitters who take care of their children for a few hours in the evening while the youngsters sleep than they do to the teachers who toil with the restless youngsters throughout the wearying day.

How shall we get the money that we need to create good schools? By gearing the financial support of education to our economy. It should be a fixed per cent of our national income. The rate should be scientifically determined and the total amount for education should vary with our national income and with the purchasing power of the dollar. It is not sensible for us to pay without much complaint nearly 5 per cent of our national income for education in times of depression and then recklessly allow our schools to deteriorate by spending only 1.6 per cent of our income in prosperous times.

We must spend at least one-half as much for schools as we do in the care of criminals and delinquents. Then we can add a million additional teachers and thus end the futile expectation that each teacher do the impossible job of two persons; then we can improve working conditions of the teachers and thus make teaching a challenge and an inspiration; then we can take steps to give due recognition to the gifted teacher and thus differentiate the professional worker from the mere transient; then we can attract the best of our young people and thus comb out the incompetent teachers with weak personalities that now downgrade what should be a great profession; then we can hold a reasonable number of men in both the elementary and the high school grades; then we can insure that a reasonable number of the teachers of our children-let us say half of them-will be really good; then we can feel confident that this nation will continue to grow strong in its influence for a better world.*

* Sorne of the facts given in this paper were previously published in The Science Teacher, February 1947 , in an article entitled "Recruiting and the Economic Stat us of the Science Teacher." 